\title{
OBSERVATIONS ON THE CHROMOSOME NUMBER OF PENNISETUM CILIARE
}

\section{Alicia Ramirez de Hernández ${ }^{1}$}

\section{INTRODUCTION}

As part of the breeding program of the Plant Breeding Department of the Agricultural Experiment Station of the University of Puerto Rico, some cytological observations have been made on different strains of "buffel grass" (Pennisetum ciliare (L.) Link, Hart; Berol) (4)². This work constitutes a preliminary report on the chromosome number of the native and some imported buffel grass strains.

Buffel grass belongs to the tribe Paniceae, family Gramineae. In India, its place of origin, it is known as "anjan grass", while in the United States it is generally known as "buffel grass". At present this Station has under propagation 11 different introduced strains. All the grasses mentioned in this study, with the exception of our native buffel grass, were obtained from Dr. E. James, Regional Plant Introduction Station, Experiment, Ga. Our native grasses were obtained from the collection of grasses at this Agricultural Experiment Station.

The Puerto Rico strain is a thin-leaved and relatively short grass found growing wild in the savanna areas and undulating lands of the southern coastal plains, especially around Salinas, Santa Isabel, and Ponce. (3)

Buffel grass is characterized as a perennial which grows from a knotted crown, the culms being geniculate, having a height of from 4 to 20 inches, though some strains may be taller. It is sparingly branched and the blades are narrow, flat, or folded with a length varying from 2 to 5 inches, or sometimes more. Seed is produced by this grass throughout the year, but the peak of the seed-bearing season is from June to September. The spikelike panicle has a length of from 1 to 4 inches, a purplish color, and is generally flexuous (4).

This grass is quite resistant to drought. Csually it is one of the last grasses found green during dry seasons and one of the first to start growing after long periods of dry weather. Since it is very palatable, it is widely preferred by grazing animals.

${ }^{1}$ Research Assistant in Cytology, Agricultural Experiment Station, University of Puerto Rico, Río Piedras, P. R. This work was done during the fiscal years 1951-52 at the Agricultural Experiment Station. The author is grateful to P. González Ríos and Efraín Boneta García for the material used, for facilities in obtaining the correct material, and general advice on this report; also to Dr. H. E. Warmke for reading and correcting the text.

${ }^{2}$ Numbers in parentheses refer to Literature Cited, p. 170. 


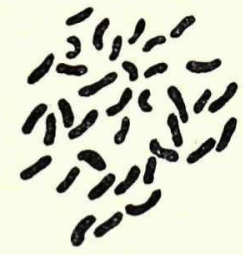

A

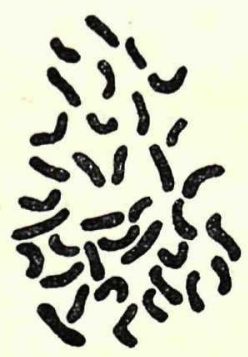

C

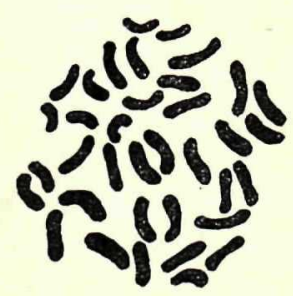

E

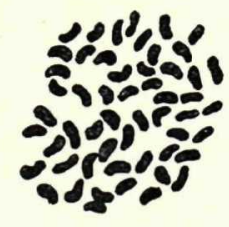

B
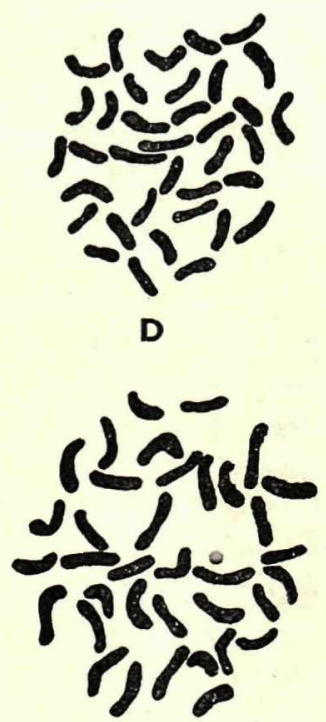

$\mathbf{F}$

Frg. 1.-Drawings showing chromosomes of $P$. ciliare strains studied: A, Native; B, anjan grass, U.S.D.A. 164601, P.R. 204; C, anjan grass, U.S.D.A. 164414, P.R. 202; D, buffel grass, U.S.D.A. 193445, P.R. 917; E, anjan grass, U.S.D.A. 164607, P.R. 203; F, buffel grass, U.S.D.A. 185641, P.R. 918.

TABLE 1.-The $2 n$ chromosome numbers of each grass strain studied, along with their U.S.D.A. and their P.R. Plant Introduction Nos., and place of origin

\begin{tabular}{|c|c|c|c|c|}
\hline Strain & $\begin{array}{l}\text { U.S.D.A. } \\
\text { P.I. No. }\end{array}$ & P.I.R. & Place of origin & $2 \mathrm{n}$ \\
\hline 1, native & - & - & Puerto Rico & 36 \\
\hline 2 , anjan grass & 164414 & 202 & $\begin{array}{l}\text { Hissar, eastern proj- } \\
\text { ect, India }\end{array}$ & 36 \\
\hline 3 , anjan grass & 164607 & 203 & $\begin{array}{l}\text { Madras College, Coim- } \\
\text { batore, India }\end{array}$ & 36 \\
\hline 4 , anjan grass & 164601 & 204 & Do. & 54 \\
\hline 5 , buffel grass & 193445 & 917 & Western Australia & 36 \\
\hline 6 , buffel grass & 185641 & 918 & Africa & 36 \\
\hline
\end{tabular}




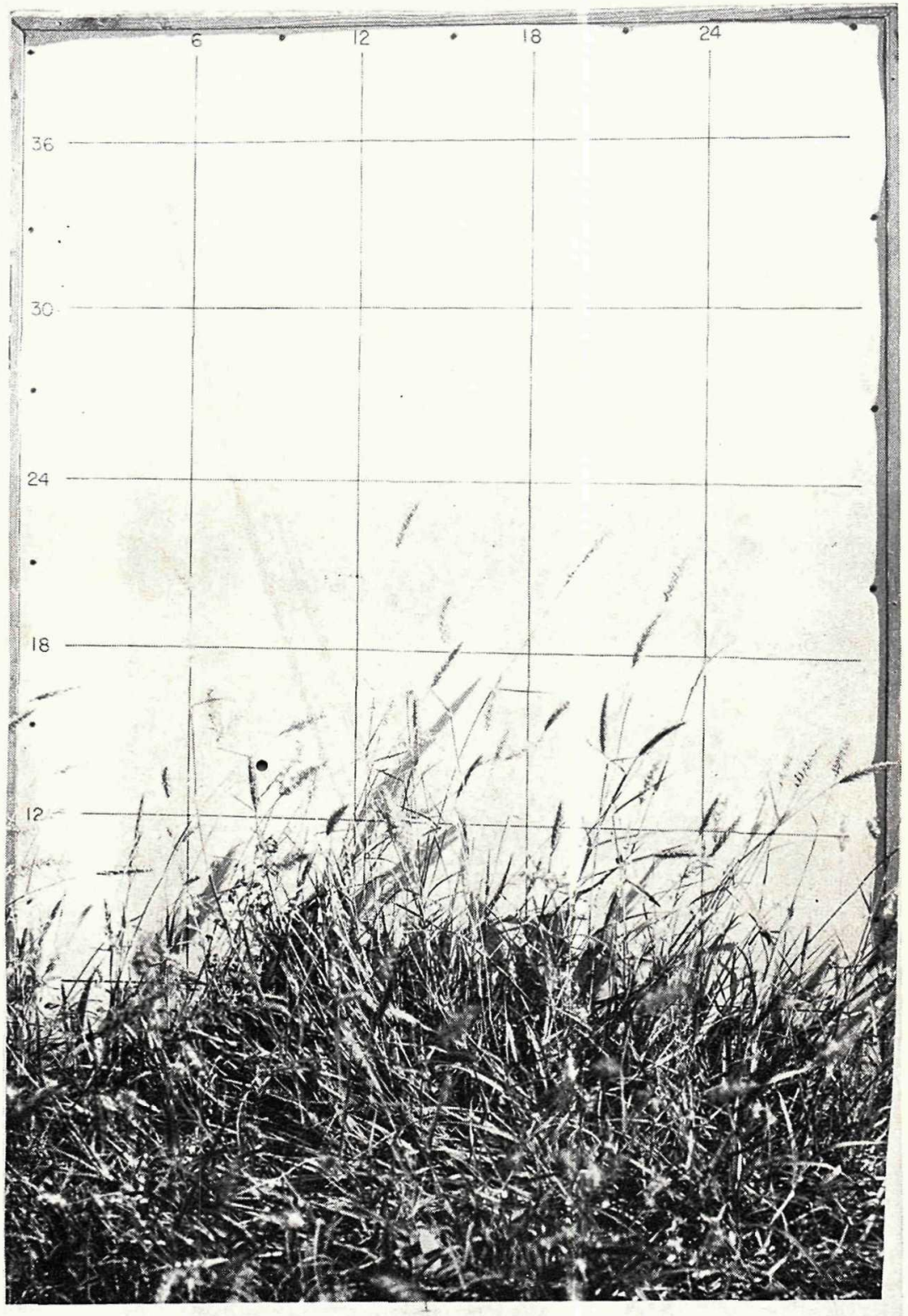

FIg. 2, A.

FIG. 2.-Appearance at $21 / 2$ months of the different strains of $P$. ciliare studied: A, Native; B, P.I. 202; C, P.I. 203; D, P.I. 204; E, P.I. 917; F, P.I. 918. 


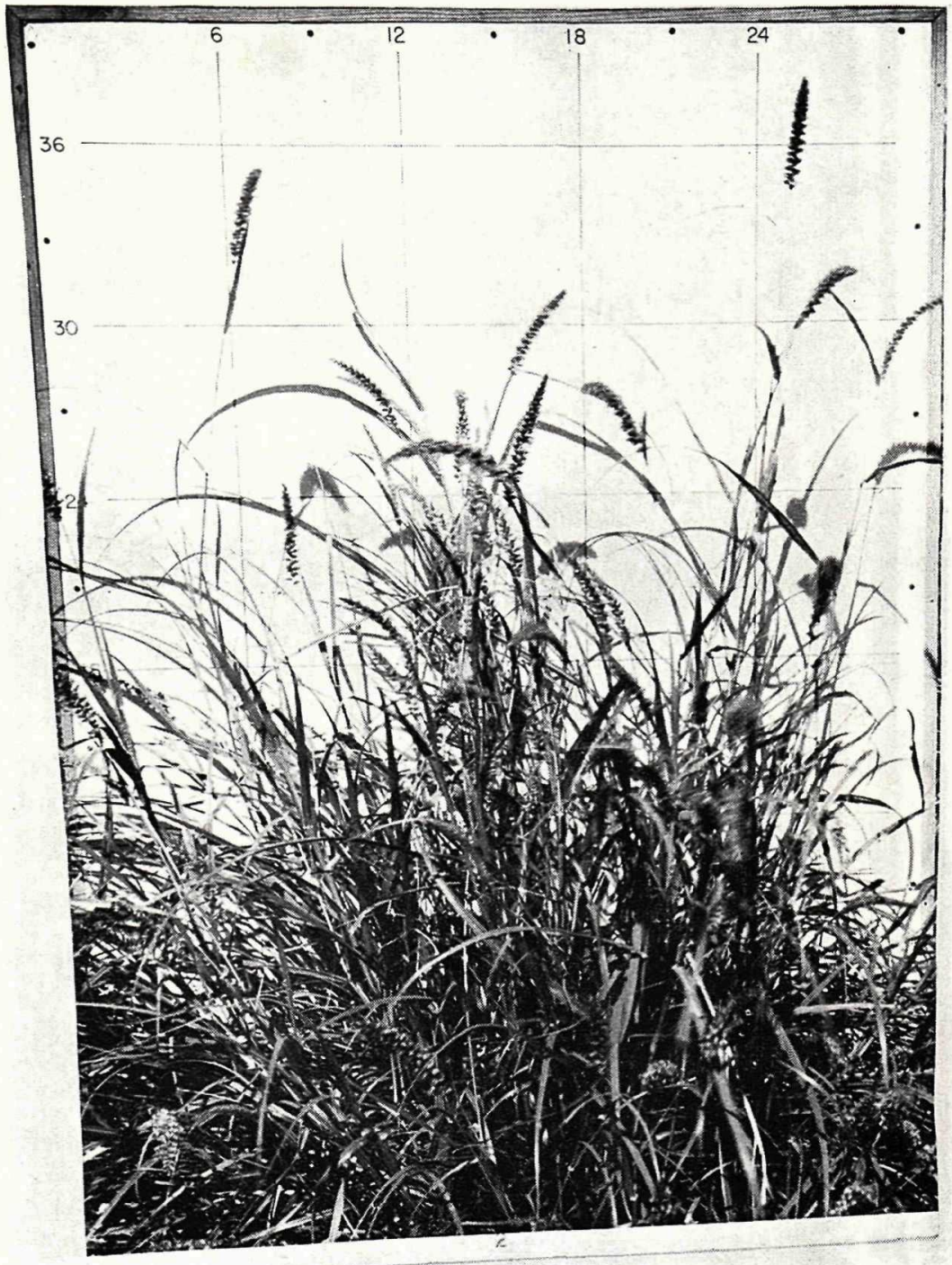

FIG. 2, B.

OBJECTIVES

Because of the high resistance to dry-weather conditions shown by buffel grass, it was considered of importance to make cytological studies of the different strains to determine the possibilities of its use in crossing with some other tall and more leafy Pennisetum species. The full investigation will cover the study of: Chromosome number, arrangement and rela- 


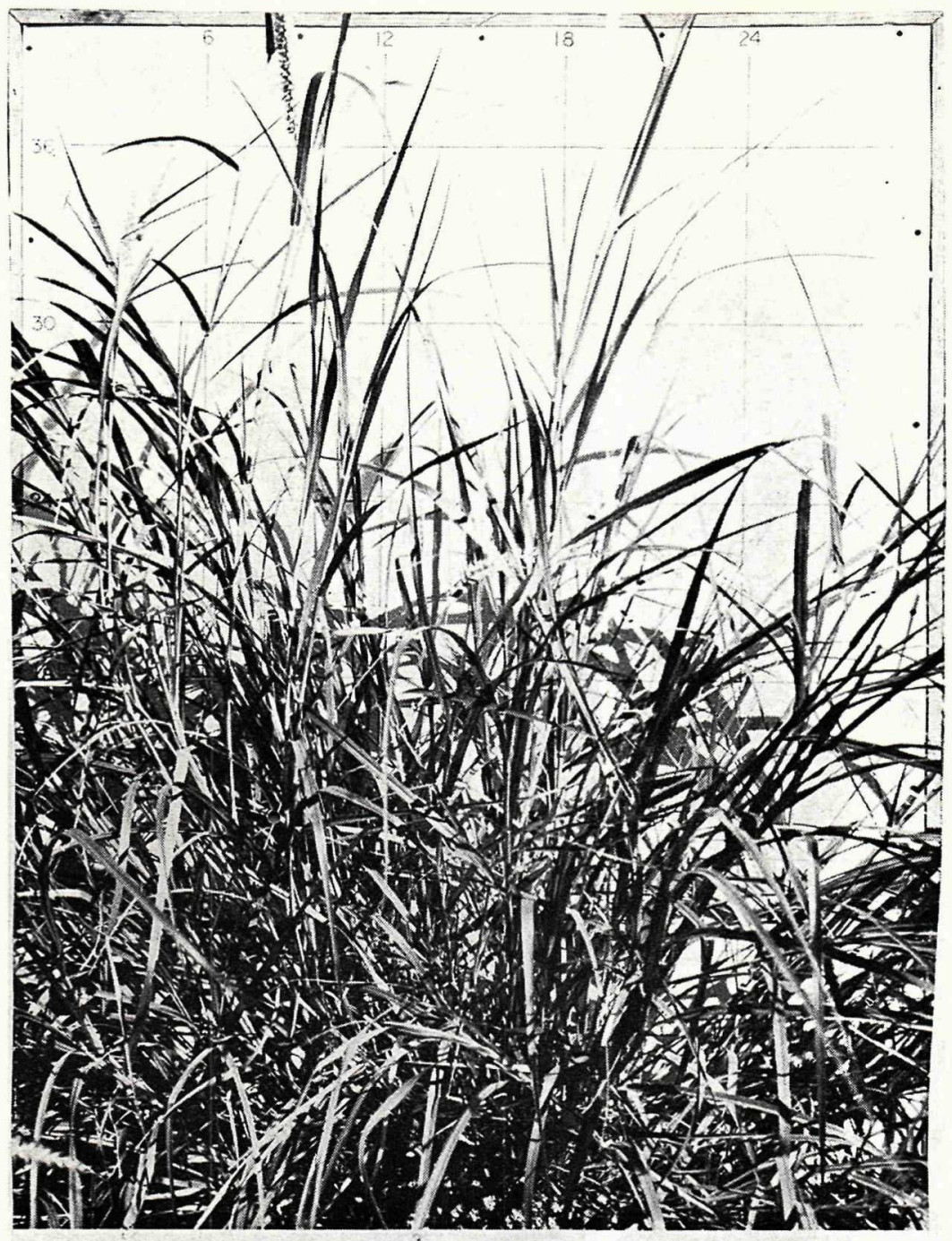

FIg. 2, C.

tion, irregular separation, and lagging chromosomes, if present, so as to obtain a better view of the breeding behavior and the possible use of buffel grass in grass improvement by hybridization and selection.

So far the cytological work carried on with this grass has consisted of chromosome counts from late-prophase mitosis in somatic root-tip cells. Nevertheless, it is our purpose to make a more detailed study of the late 


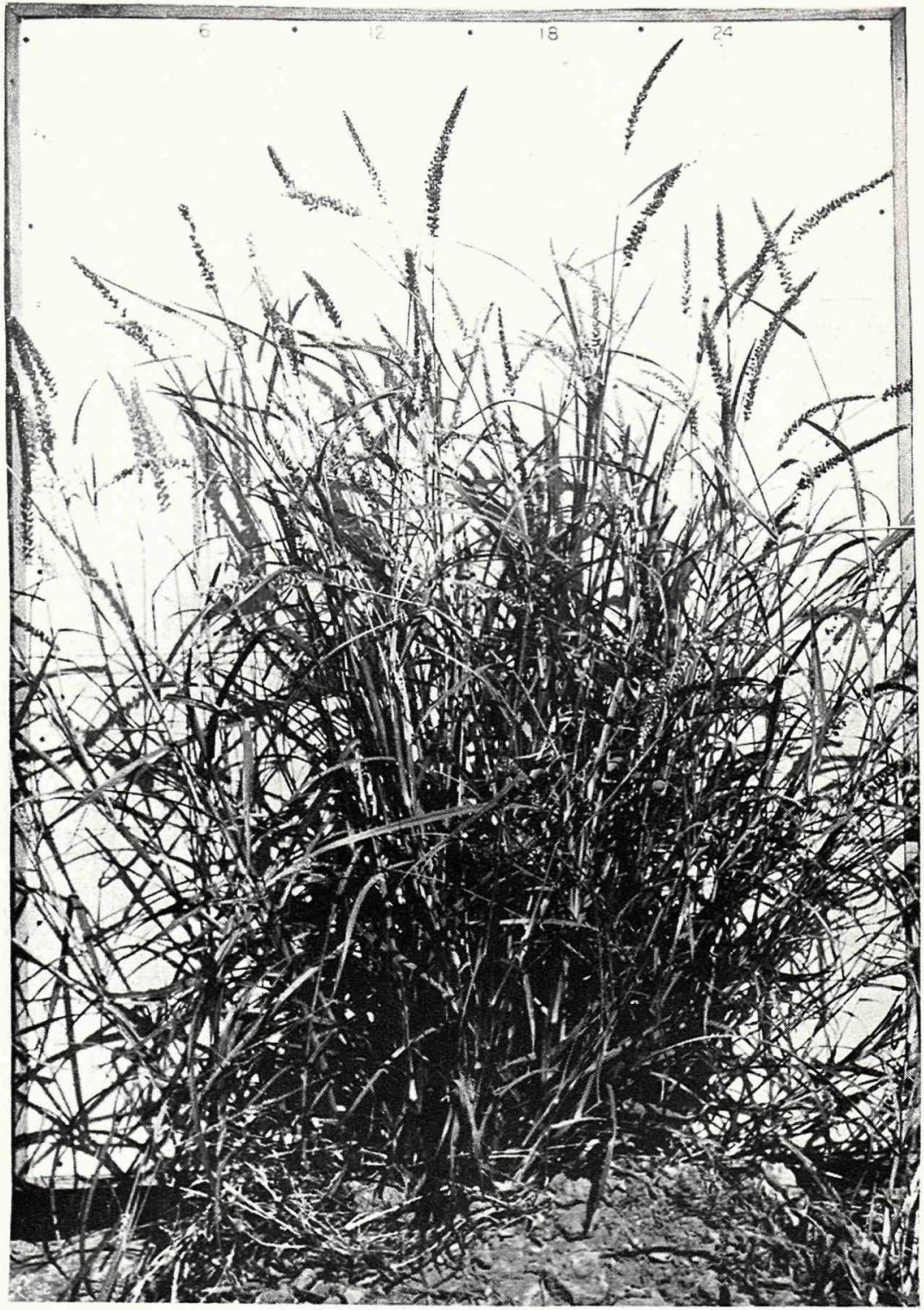

FIG. 2, D.

diakinesis stage of the meiotic division in pollen mother cells, which will be reported later. For such studies of meiosis young inflorescenses are fixed in absolute-acetic fixative and anthers smeared in propio- and acetocarmine stains. 


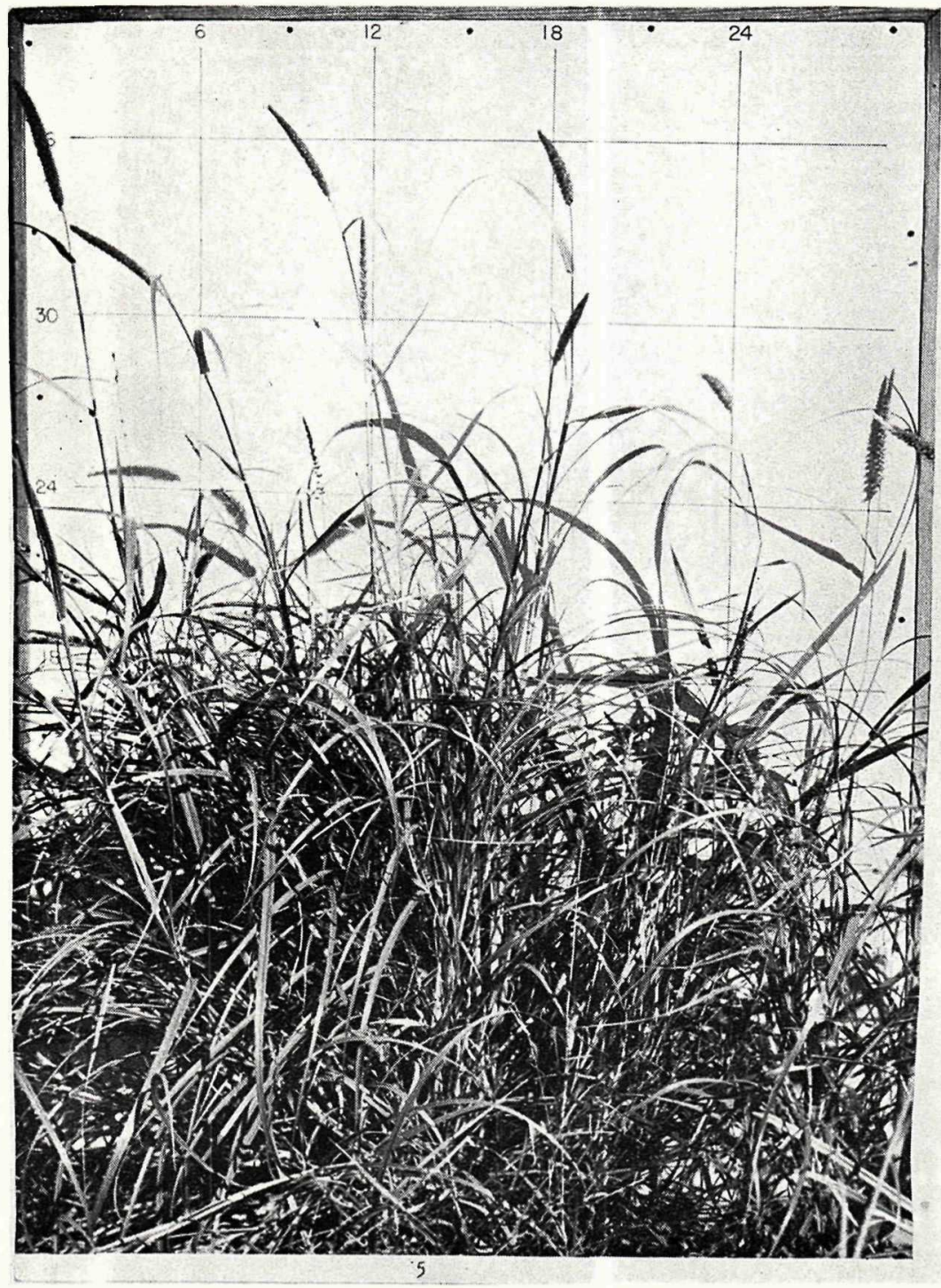

FIG. 2, E.

\section{MATERIALS AND METHODS}

Vegetative material was grown in the greenhouse for root-tip production. All material to be used was planted in 3- and 4-inch pots. In some cases seed were planted while in others cuttings or sprigs from plots of the grass collection were used. Approximately 1 month after planting was required 


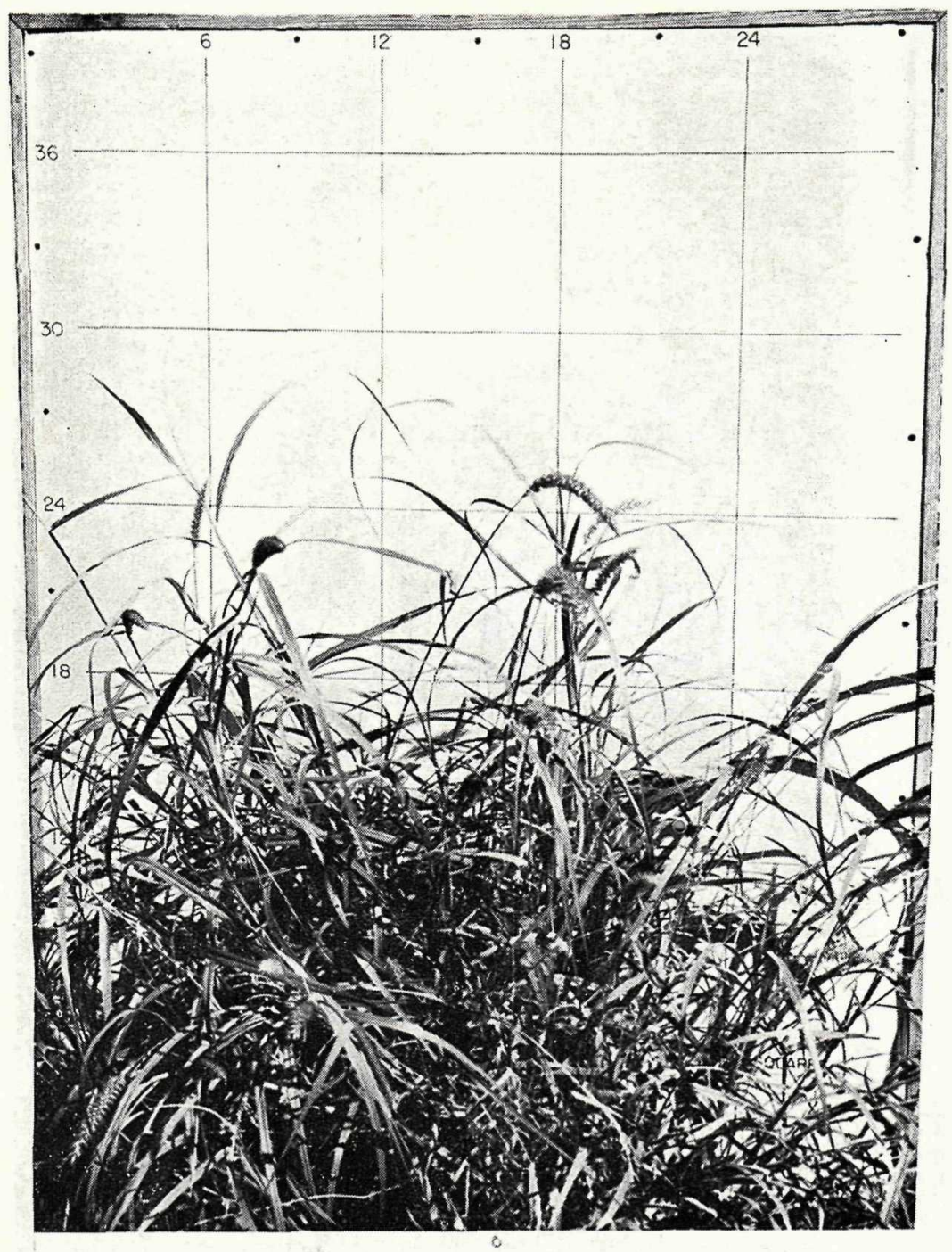

FIc. 2, F.

for obtaining appropriate material consisting of white, thick, round, clean root tips.

Root tips from all the grasses studied in this report were collected between 8:00 a.m. and 10:00 p.m. The fixation was done with Belling's Modified Navashin fluid, or with Randolph Modified Navashin fluid (CRAF) The material was left on the fixatives approximately 24 hours. 
The root-tip material was embedded and sectioned according to the standard procedures of the paraffin method (5). Cross sections were cut from 8 to 10 microns and were stained by the Feulgen technique (5).

Chromosome counts and drawings were made with the aid of a Spencer camera lucida. The drawings were made at table level using a $30 \times$ compensating ocular and a 1.8-mm. fluorite oil immersion, objective; therefore all have the same degree of magnification (see fig. 1).

\section{RESULTS}

Table 1 lists the $2 \mathrm{n}$ chromosome number obtained for each strain, the original location of the grass, and the U.S. Department of Agriculture Plant Introduction No. as well as the Puerto Rico Introduction No.

TABLE 2.-Growth habits and other vegetative details of the various strains of $\mathrm{P}$. ciliare, studied

\begin{tabular}{|c|c|c|c|c|c|}
\hline \multirow[b]{2}{*}{ No. } & \multirow[b]{2}{*}{ Strain } & \multirow[b]{2}{*}{ Growth habit } & \multirow{2}{*}{$\begin{array}{c}\text { Average } \\
\text { height }\end{array}$} & \multicolumn{2}{|l|}{ Spikes } \\
\hline & & & & Color & \begin{tabular}{|} 
Approxi- \\
mate \\
size
\end{tabular} \\
\hline & & & Feet & & inches \\
\hline 1 & Native & $\begin{array}{l}\text { Bunch, slightly decum- } \\
\text { bent }\end{array}$ & $1-1 \frac{1}{2}$ & Light brown & 2 \\
\hline 2 & P.I. 202 & $\begin{array}{l}\text { Bunch, erect, heavy } \\
\text { tillery }\end{array}$ & $2-2 \frac{1}{2}$ & Brownish & 4 \\
\hline 3 & P.I. 203 & $\begin{array}{l}\text { Bunch, erect, good- } \\
\text { quality forage }\end{array}$ & 3 & Light brown & $5-6$ \\
\hline 4 & P.I. 204 & Bunch, erect & $21 / 2-3$ & $\begin{array}{l}\text { From light brown } \\
\text { to almost black }\end{array}$ & $4-5$ \\
\hline 5 & P.I. 917 & do. & $2-3$ & Brownish & $41 / 2$ \\
\hline 6 & P.I. 918 & Bunch, decumbent & $21 / 2$ & Light brown & 4 \\
\hline
\end{tabular}

Figure 1 shows a series of camara lucida drawings all of which have the same magnification. These chromosome counts were derived from different strains of species of Pennisetum (Penicillaria) (2) not previously reported in Darlington's Chromosome Atlas of Cultivated Plants.

Figure 2 shows the different strains of $P$. ciliare described in this work. All of them were $2 \frac{1}{2}$ months old when the photographs were taken. Vegetative appearance and other details are shown in table 2 .

\section{SUMMARY}

Chromosome counts are given for various strains of Pennisetum ciliare, commonly named "buffel grass" and "anjan grass".

All strains of $P$. ciliare reported upon herein are tetraploids, with but one exception, which seems to be a hexaploid. 


\section{RESUMEN}

Se ha informado en esta publicación el número de cromosomas de algunas formas de $P$. ciliare, comunmente conocida como "buffel grass" o "yerba anjan".

Se observó que todas las yerbas informadas aquí son tetraploide, con una excepción, que parece ser hexaploide.

\section{LITERATURE CITED}

1. Brown, Walter V., A Cytological study of some Texas gramineae, Bull. Torrey Botanical Club and Torreya, $77(2) 1950$.

2. Darlington, C. D. and Janaki Ammal, E. K., Chromosomes Atlas of Cultivated Plants, George Allen and Unwin Ltd., London, 1945.

3. García Molinari, Ovidio, Grassland and grasses of Puerto Rico, Bull. 102. Agricultural Experiment Station, Río Piedras, P. R., August 1952.

4. Hitchcock, A. S., 1935 Manual of the grasses of the West Indies, Misc. Publ. 243, U. S. Dept. of Agri., Washington, D. C., 1936.

5. Johansen, D. A., Plant Microtechnique, McGraw Hill Book Co., Inc., New York and London, 1940. 